\title{
ACCUMULATION AND VARIATION OF ROSMARINIC ACID CONTENT IN ORTHOSIPHON STAMINEUS BENTH. BASED ON PHENOLOGICAL STAGES
}

\author{
DO MINH TRUONG \\ Thai Nguyen University \\ NGUYEN THI BICH THU, LE THANH NGHI \\ National Institute of Medicinal Materials
}

\begin{abstract}
Orthosiphon Stamineus Benth. (Lamiaceae) is a medicinal herb trusted for many centuries for treating ailments of the kidney, bladder stone, urinary tract infection, liver and bladder problems, diabetes, rheumatism and gout. It is also used to reduce cholesterol and blood pressure. Rosmarinic acid is one of the most important and specific active compound in $O$. stamineus. The biological effects of rosmarinic acid have been proved. In the research, plant material was harvested at different phenological stages (before budding, full flowering, and after flowering) of the life cycle of the species. The content of rosmarinic acid in samples was measured using HPLC method. Results showed that the accumulation of rosmarinic acid in leaf was higher than that in other organs. The content of rosmarinic acid was increased gradually from before budding stage to flowering stage and reached the maximum content at time of after flowering stage. The content of rosmarinic acid of the $2^{\text {nd }}$ variety was higher than that of the $1^{\text {st }}$ variety at the same time $(\mathrm{p}<0.05)$.
\end{abstract}

Keywords: Rosmarinic acid, Orthosiphon stamineus, accumulation, variation.

Orthosiphon stamineus Benth. $(O$. stamineus) is one of the oldest and still most popular medicinal plants. It is a representative of the Lamiaceae family that is known for many medicinal plants commonly used in South-east Asia's traditional medicine and is known in Western herbalist as Java Tea. It has also been included in the European Pharmacopoeia under this name. $O$. samineus is a popular herb in Malaysia, Indonesia, Thailand, Vietnam, and neighboring countries. Its applications include urinary system diseases such as kidney and bladder inflammation and lithiasis due to its mild diuretic and ati-inflammatory action. It is also claimed to be an efficient drug for fever, rheumatism, hypertension, and even gonorrhea and syphilis [2, 3, 8, 9].

$O$. stamineus contains several chemically active constituents, but one of the most important classes of compounds is the phenol group. Twenty phenol compounds were isolated, including nine lipophilic flavones, two flavonol glycosides, and nine caffeic acid derivatives, such as rosmarinic acid, 2,3-dicaffeoyltartaric acid, were identified and quantified by high performance liquid chromatography (HPLC) [2]. Other chemical constituents of $O$. stamineus include isopimarane-type diterpenes, highly oxygenated staminane-type diterpenes, pentacyclic triterpenes etc [10].

Rosmarinic acid exhibits various pharmacological activities including prevention of oxidation of low density lipoprotein, inhibition of murine cell proliferative activity and of cyclooxygenase, and anti-allergic action. The biological activity of rosmarinic acid is described as antibacterial, antiviral, and antioxidative. Its activity especially against rheumatic and inflammatory conditions makes it a sought-after substance for use in phytotherapy. More recently, rosmarinic acid was reported to have anti-HIV activities [4, 6, 7, 9].

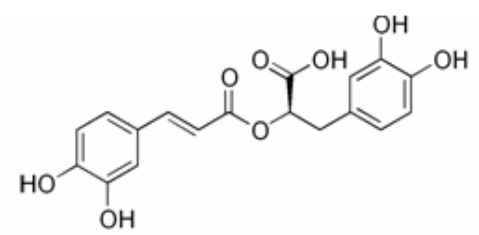

Fig. 1. Chemical structure of rosmarinic acid 
The aim of this work is to investigate the accumulation and variation of rosmarinic acid content in aerial part from different phenological stages of two varieties cultivated $O$. stamineus. grown in some localities in Vietnam.

\section{MATERIALS AND METHODS}

\section{Plant materials}

The first variety was introduced from Soviet Union in 1980 and the second variety was introduced from Malaysia in 2004. The two varieties were determined the scientific name Orthosiphon stamineus Benth. by Botanical Department and medicinal plant resources, National Institute of Medicinal Materials.

Plants of $O$. stamineus were cultivated in Research Center of Medicinal Plants (RCMP) Thanh Tri district, Hanoi city; Xuan Mai (XM) town, Chuong My district, Hanoi city and Thinh Duc commune, Thai Nguyen (TN) city in Vietnam. Cultures on plots of $12 \mathrm{~m}^{2}$ were planted on a light sand-loam soil in a sunny locality; plants' spacing $40 \mathrm{~cm} \times 40 \mathrm{~cm}$; fertilization with $(\mathrm{kg} / \mathrm{ha}): 90 \mathrm{~N}, 60 \mathrm{P}_{2} \mathrm{O}_{5}, 80$ $\mathrm{K}_{2} \mathrm{O}$; irrigation one a week in the dry period; no pesticides were used. The herb was harvested at different phenological stages: before budding, full flowering, and after flowering (after full flowering 45 days) of the life cycle of the species. The samples were obtained by cutting the herb manually in a height of about $20 \mathrm{~cm}$ above ground. Harvests were always carried out on sunny days, at about 11 a.m. The herb was dried at $32^{\circ} \mathrm{C}$ and stored in paper sacks in a dark, cool, and dry depository.

\section{Chemicals and reagents}

Standard compound of rosmarinic acid was purchased from Indofine Chemical Co. (Hillsborough, NJ, USA). Solvents used for chromatography were obtained from Merck (Darmstadt, Germany).

\section{Extraction and HPLC analysis}

The British Pharmacopoeia protocol recommended in the Rosmarinus officinalis monograph was used [1]. To $1 \mathrm{~g}$ of powder of the plant add $230 \mathrm{ml}$ of alcohol (50 percent $\mathrm{v} / \mathrm{v}$ ). Boil in a water-bath under a reflux condenser for 1 hour. Allow to cool and filter. Rinse the filter with $10 \mathrm{ml}$ of alcohol (50 percent $v / v)$. Combine the filtrate and rinsing in a volumetric flask and dilute to $250 \mathrm{ml}$ with alcohol $(50$ percent $v / v$ ). The extract was subjected to quantitative HPLC analysis.

HPLC analysis was performed using the HPLC system (Shimadzu, Japan) with a manual injector, UV-VIS detector. The analytical column was a revered phase $\mathrm{C} 18,4 \mathrm{~mm} \times 250$ $\mathrm{mm}, 5 \mu \mathrm{m}$ particle size. The temperature was maintained at $25{ }^{\circ} \mathrm{C}$, with injection volume of 20 $\mu \mathrm{l}$ and flow rate of $0.5 \mathrm{ml} / \mathrm{min}$. Rosmarinic acid was separated with methanol-water $(40: 60 \mathrm{v} / \mathrm{v})$ as mobile phase $(\mathrm{pH} \mathrm{2,} \mathrm{adjusted} \mathrm{with} \mathrm{phosphoric}$ acid). Spectra were recorded at $320 \mathrm{~nm}$. The external standard method was used for the HPLC quantification. The results were reported as $\mathrm{mg} / \mathrm{g}$ dry weight.

\section{Statistical analysis}

Experimental results were means of three parallel measurements and analyzed by Microsoft Excel.

\section{Place and time of study}

O. stamineus was grown in the Research Center of Medicinal Plants Thanh Tri district, Hanoi city; Xuan Mai town, Chuong My district, Hanoi city, and Thinh Duc commune, Thai Nguyen city in Vietnam.

Chemical experiments were carried out at Department of Analytical chemistry and Standardization, National Institute of Medicinal Materials, Vietnam. This study was carried out from January, 2009 to December, 2009.

\section{RESULTS}

In the present study, acid rosmarinic was determined by HPLC using the isocratic condition methanol: water $(40: 60 v / v), \mathrm{pH} 2$. The peak of rosmarinic acid was confirmed by comparison of its retention time with reference standards. The rosmarinic acid standard was resolved and eluted at $6.400 \mathrm{~min}$.

1. The accumulation and variation of rosmarinic acid content of two varieties grown in the Research Center of Medicinal Plants 
The content of rosmarinic acid in leaf was higher than those in whole plant and stem branch, indicated that leaf was the most accumulated organ of rosmarinic acid. In whole plant samples, rosmarinic acid content of the $1^{\text {st }}$ variety at after flowering stage was 1.5 times higher than those at before budding stage and 1.3 times higher than those at full flowering stage $(\mathrm{p}<0.05)$. For the $2^{\text {nd }}$ variety, the content of rosmarinic at after flowering stage was 1.7 times higher than those at before budding stage and 1.3 times higher than those at full flowering stage $(\mathrm{p}<0.01)$. In leaf samples of the $1^{\text {st }}$ variety, the content of rosmarinic at after flowering stage was 1.9 times higher than those at before budding stage and 1.5 times higher than those at full flowering stage $(\mathrm{p}<0.01)$. In leaf samples of the $2^{\text {nd }}$ variety, the content of rosmarinic at after flowering stage was 1.7 times higher than those at before budding stage and 1.4 times higher than those at full flowering stage $(\mathrm{p}<0.01)$.

Thus, the common tendency was increased gradually the content of rosmarinic acid in leaf and branch of $O$. stamineus from before budding period to after flowering period (fig. 2).

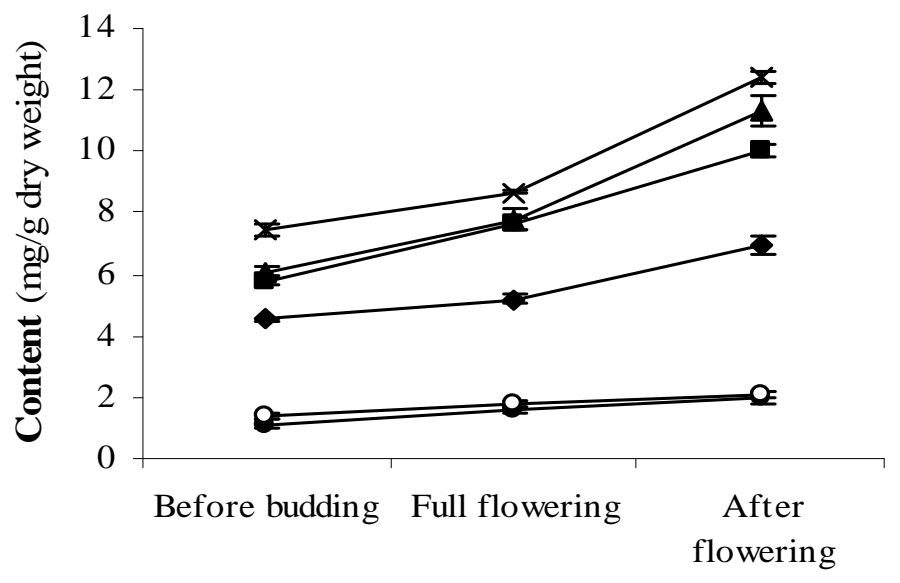

Developmental stage

Fig. 2. Variations of rosmarinic acid content of two varieties that grown in the Research Center of Medicinal Plants.

Notes: Whole plant of the $1^{\text {st }}$ variety $(\bullet)$, whole plant of the $2^{\text {nd }}$ variety $(\boldsymbol{\bullet})$, leaf of the $1^{\text {st }}$ variety $(\mathbf{\Delta})$, leaf of the $2^{\text {nd }}$ variety $(\mathrm{x})$, branch of the $1^{\text {st }}$ variety $(\bullet)$, branch of the $2^{\text {nd }}$ variety $(\mathrm{o})$. Symbol (I) in this graph is standard divination with $\mathrm{n}=3$.

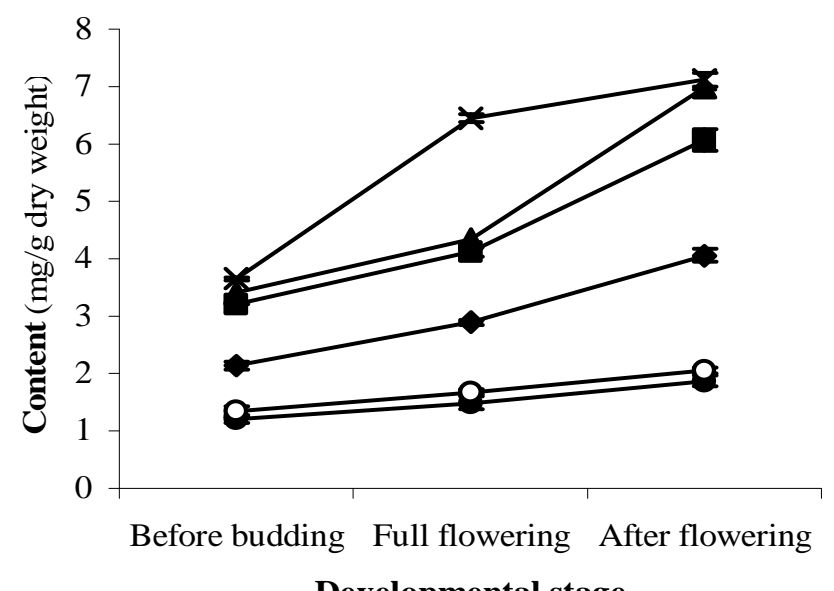

Fig. 3. Variations of rosmarinic acid content of two varieties that grown in Thai Nguyen

Notes: as fig.2. 
2. The accumulation and variation of rosmarinic acid content of two varieties grown in Thai Nguyen

The accumulation of rosmarinic acid in two varieties grown in Thai Nguyen was similar to that grown in the Research Center of Medicinal Plants. Leaf was the most accumulated organ of rosmarinic acid at everytime. In whole plant samples, rosmarinic acid content of the $1^{\text {st }}$ variety at after flowering stage was 1.9 times higher than those at before budding stage and 1.4 times higher than those at full flowering stage $(\mathrm{p}<0.05)$. For the $2^{\text {nd }}$ variety, the content of rosmarinic at after flowering stage was 1.9 times higher than those at before budding stage and 1.5 times higher than those at full flowering stage $(\mathrm{p}<0.01)$. In leaf samples of the $1^{\text {st }}$ variety, the content of rosmarinic at after flowering stage was 2 times higher than those at before budding stage and 1.6 times higher than those at full flowering stage $(\mathrm{p}<0.01)$. In leaf samples of the $2^{\text {nd }}$ variety, the content of rosmarinic at after flowering stage was 1.9 times higher than those at before budding stage and 1.1 times higher than those at full flowering stage $(\mathrm{p}<0.01$ and $\mathrm{p}<0.05)$.
Thus, the common tendency was increased gradually the content of rosmarinic acid in leaf and branch of $O$. stamineus from before budding period to after flowering period (fig. 3).

3. The accumulation and variation of rosmarinic acid content of the 2 nd variety grown in Xuan Mai

The content of rosmarinic acid in leaf samples at three times was higher whole plant samples $(\mathrm{p}<0.01)$. Indicating leaf is the most accumulated organ of rosmarinic acid in $O$. stamineus. The content of rosmarinic acid in whole plant samples at after flowering stage was 2.2 times higher than those at before budding stage and 1.6 times higher than those at full flowering stage $(\mathrm{p}<0.01)$. In leaf samples, the content of rosmarinic at after flowering stage was 2.3 times higher than those at before budding stage and 1.6 times higher than those at full flowering stage $(\mathrm{p}<0.01)$.

Thus, the common tendency was increased gradually the content of rosmarinic acid in leaf and branch of the $2^{\text {nd }}$ variety grown in Xuan Mai from before budding period to after flowering period (fig. 4).

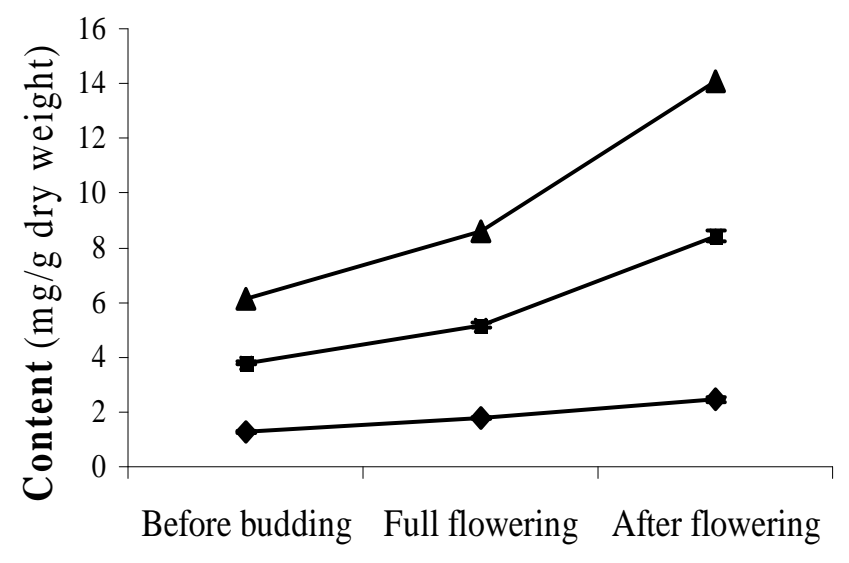

Developmental stage

Fig. 4. Variations of rosmarinic acid content of the $2^{\text {nd }}$ variety that grown in Xuan Mai Notes: Whole plant (๘), leaf $(\mathbf{\Lambda})$, branch $(\bullet)$. Symbol (I) in this graph is standard divination with $\mathrm{n}=3$.

The content of rosmarinic acid in two varieties of Orthosiphon stamines grown at three areas showed in table 1 and table 2.

The content of rosmarinic acid in whole plant of the $2^{\text {nd }}$ variety in RCMP was higher than those at other areas $(\mathrm{p}<0.01)$. The content of rosmarinic acid of the $2^{\text {nd }}$ variety in RCMP at before budding, full flowering and after flowering stage was $5.78 \pm 0.16,7.64 \pm 0.21$, and $10.03 \pm 0.17 \mathrm{mg} / \mathrm{g}$ dry weight, respectively. The $1^{\text {st }}$ variety in Thai Nguyen possesses lowest content of rosmarinic acid at everytime. 
Comparison rosmarinic acid content in whole plant samples of two varieties of Orthosiphon stamineus at three areas (mg/g dry weight)

\begin{tabular}{|c|c|c|c|}
\hline \multirow{2}{*}{$\begin{array}{lll}\text { Variety } & \text { Time } \\
\end{array}$} & Before budding & Full flowering & After flowering \\
\hline & $\bar{X} \pm \mathrm{SD}$ & $\bar{X} \pm \mathrm{SD}$ & $\bar{X} \pm \mathrm{SD}$ \\
\hline the $1^{\text {st }}$ variety in RCMP & $4.52 \pm 0.06$ & $5.21 \pm 0.12$ & $6.95 \pm 0.32$ \\
\hline the $1^{\text {st }}$ variety in TN & $2.14 \pm 0.07$ & $2.89 \pm 0.04$ & $4.06 \pm 0.12$ \\
\hline the $2^{\text {nd }}$ variety in RCMP & $5.78 \pm 0.16$ & $7.64 \pm 0.21$ & $10.03 \pm 0.17$ \\
\hline the $2^{\text {nd }}$ variety in TN & $3.21 \pm 0.01$ & $4.12 \pm 0.08$ & $6.07 \pm 0.19$ \\
\hline the $2^{\text {nd }}$ variety in $\mathrm{XM}$ & $3.78 \pm 0.06$ & $5.16 \pm 0.09$ & $8.42 \pm 0.20$ \\
\hline
\end{tabular}

Table 2

Comparison rosmarinic acid content in leaf samples of two varieties of Orthosiphon stamineus at three areas ( $\mathrm{mg} / \mathrm{g}$ dry weight)

\begin{tabular}{|c|c|c|c|}
\hline \multirow{2}{*}{ Variety Time } & Before budding & Full flowering & After flowering \\
\hline & $\bar{X} \pm \mathrm{SD}$ & $\bar{X} \pm \mathrm{SD}$ & $\bar{X} \pm \mathrm{SD}$ \\
\hline the $1^{\text {st }}$ variety in RCMP & $6.07 \pm 0.23$ & $7.79 \pm 0.33$ & $11.32 \pm 0.51$ \\
\hline the $1^{\text {st }}$ variety in TN & $3.42 \pm 0.14$ & $4.34 \pm 0.08$ & $6.98 \pm 0.13$ \\
\hline the $2^{\text {nd }}$ variety in RCMP & $7.45 \pm 0.19$ & $8.68 \pm 0.09$ & $12.45 \pm 0.19$ \\
\hline the $2^{\text {nd }}$ variety in TN & $3.65 \pm 0.03$ & $6.45 \pm 0.07$ & $7.12 \pm 0.12$ \\
\hline the $2^{\text {nd }}$ variety in XM & $6.12 \pm 0.11$ & $8.59 \pm 0.06$ & $14.07 \pm 0.17$ \\
\hline
\end{tabular}

The content of rosmarinic acid in leaf of the $2^{\text {nd }}$ variety in RCMP was higher than those at other areas at before budding and full flowering stage (7.45 and $8.68 \mathrm{mg} / \mathrm{g}$ dry weight, respectively). However, at after flowering stage the content of rosmarinic acid of the $2^{\text {nd }}$ variety at Xuan Mai was higher than other areas (14.07 $\mathrm{mg} / \mathrm{g}$ dry weight).

\section{DISCUSSION}

Rosmarinic acid has become a compound attracting much interest amongst the active principles of Orthosiphon stamineus Benth in recent years. It was proven to be the main substance responsible for the healing activity of $O$. stamineus extracts in Herpes simplex treatment. Its antioxidative properties are known as well. The content of the other important active compound of the plant is known to depend considerably upon extrinsic and intrinsic factors, including soil and climatic conditions, plant ontogenesis phases, harvest and drug storing conditions.

Rosmarinic acid is a simple phenolic compound and there are several different analytical methods described in the literature to determine its content in Lamiaceae species, including UV-VIS spectrophotometer, gas chromatography, and HPLC [2], [4]. The simple isocratic method was modified in our work to fit our chromatographic conditions was used to better separate the desired compound.

In this study, rosmarinic acid content in $O$. stamineus may be affected by environmental changes. Content of rosmarinic acid had a peak at after flowering period in summer and autumn, which was higher than the content measured in spring and winter. In summer, the plant suffers the greater stress from environment, such as UV irradiation, high temperature, which may lead to the accumulation of rosmarinic acid. The previous studies showed that phenolic acid might be accumulated in plants mainly in the following two ways: (1) in response to an environmental stress; (2) in response to cell damage or infection by a pathogen microorganism [5].

High temperature may be one of the important factors affecting the change of rosmarinic acid content, because thermal stress 
induces the production of rosmarinic acid by activating their biosynthesis as well as inhibiting their oxidation. These results indicated that rosmarinic acid in $O$. stamineus may be sensitive to seasonal temperature changes.

Growth status may be linked to accumulation of rosmarinic acid. In autumn, plant growth is ceased and photosynthetic are reallocated to the secondary metabolites, such as phenolic acids, flavonoids, tannins and other phenolics, therefore more phenolic acids accumulate, then peak in autumn. In spring, photosynthesis would intensify when leaves are hardened. Greater carbohydrates are allocated to primary metabolites in preparation for growth of plant, while accumulation of secondary metabolites is declined. Hence phenolic acid content is low over the period of spring. The low phenolic acid content in winter may be due to the lower photosynthetic photon flux density as well as low temperature. These discoveries indicated that phenolic acids content (such as rosmarinic acid) in $O$. stamineus had a large seasonal variation.

\section{CONCLUSION}

In the research, plant material was harvested at different phenological stages (before budding, full flowering, and after flowering stage) of the life cycle of the species. The content of rosmarinic acid in samples was measured using HPLC method. Results showed that the accumulation of rosmarinic acid in leaf was higher than that in other organs. The content of rosmarinic acid was increased gradually from before budding stage to flowering stage and reached the maximum content at time of after flowering stage (after full flowering 45 days). The content of rosmarinic acid of the $2^{\text {nd }}$ variety was higher than that of the $1^{\text {st }}$ variety at the same time $(\mathrm{p}<0.05)$.

\section{REFERENCES}

1. The British Pharmacopoeia Commission, 2009: British Pharmacopoeia 2009, Ministry of Health, England.

2. Akowuah G. A. et al., 2004: Food Chemistry, 87: 559-566.

3. Akowuah G. A. et al., 2005: Food Chemistry, 93: 311-317.

4. Hossain M. A. et al., 2009: Food Chemistry, 113: 185-190.

5. Johanna B. M., 2007: Variation of active constituents in Euclea natalensis based on seedling states, seasons, and fertilizers, Submitted in partial fulfillment of the requirements for the degree of Magister scientiae, University of Pretoria.

6. Park S. U., 2008: African Journal of Biotechnology, 7(25): 4959-4965.

7. Petersen M., Simmonds M. S., 2003: Phytochemistry, 62(2): 5-121.

8. Sahib H. B. et al., 2009: International Journal of Pharmacology, ISSN 1811-7775.

9. Sahib H. B. et al., International Journal of Pharmacology, 5(4): 273-276.

10. Yasuhiro T. et al., 2000: Chemical Pharmacy Bulletin, 48(11): 1711-1719.

\title{
SỰ TÍCH LUỸ VÀ BIẾN ĐộNG HÀM LƯợNG AXIT ROSMARINIC TRONG CÂY RÂU MÈO (ORTHOSIPHON STAMINEUS BENTH.) QUA MỘT SỐ GIAI ĐOẠN PHÁT TRIỂN
}

\author{
ĐỖ MINH TRƯờNG, NGUYỄN THỊ BÍCH THU, LÊ THÀNH NGH!̣
}

\section{TÓM TÁ́T}

Axit rosmarinic là một acid phenolic có trong tất cả các loài thuộc họ Boraginaceae, nhưng trong họ Lamiaceae, acid rosmarinic chỉ có trong các loài thuộc phân họ Nepetoideae. Acid rosmarinic có hoạt tính 
chống oxy hóa, kháng viêm và kháng khuẩn. Hoạt tính chống oxy hóa của acid rosmarinic mạnh hơn vitamin E. Acid rosmarinic giúp ngăn chặn sự hủy hoại tế bào bởi các gốc tự do, qua đó làm giảm nguy cơ ung thư và chứng xơ vữa động mạch. Mục đích của nghiên cứu này là theo dõi sự tích luỹ và biến động hàm lượng acid rosmarinic của hai giống râu mèo (Orthosiphon stamineus) qua một số giai đoạn chính trong quá trình sinh trưởng phát triển của loài này. Hàm lượng acid rosmarinic trong các mẫu râu mèo được xác định bằng sắc ký lỏng hiệu năng cao. Kết quả nghiên cứu cho thấy, lá là cơ quan tích luỹ nhiều acid rosmarinic nhất trong cây râu mèo; hàm lượng acid rosmarinic trong các mẫu toàn thân, cành và lá của hai giống râu mèo tăng dần từ giai đoạn trước ra hoa đến giai đoạn sau nở hoa; Trong cùng một thời điểm, hàm lượng acid rosmarinic của giống 2 cao hơn hàm lượng acid rosmarinic của giống 1 tại cùng một thời điểm, sự khác biệt có ý nghĩa thống kê $(\mathrm{p}<0,05)$.

Tù khoá: acid rosmarinic, Orthosiphon stamineus, sự tích lũy, sụ biến động.

Ngày nhận bài: 4-3-2010 